\title{
Seasonal grazing of Columbia milkvetch by cattle on rangelands in British Columbia
}

\author{
WALTER MAJAK, LEO STROESSER, JOHN W. HALL, DEE A. QUINTON AND \\ HARRIET E. DOUWES
}

Authors are toxic plant biochemist and range manager, Agriculture and Agri-Food Canada Range Station, Kamloops, B.C. V2B 8A9; statistician, Agriculture and Agri-Food Canada Pacific Agricultural Research Centre, Vancouver, B.C. V6T IX2; and range scientist and range technician, Agriculture and Agri-Food Canada Range Station, Kamloops, B.C. V2B 8A9.

\begin{abstract}
There is a dearth of knowledge on the selection and utilization of Columbia milkvetch (Astragalus miser Dougl. ex Hook. var. serotinus) by grazing livestock on rangelands in British Columbia. Four grazing trials were conducted with cattle on Columbia milkvetch range in southern interior British Columbia. In the first 2 trials during 1990 and 1991 cattle grazed an upper grassland site in late spring. In 1992 and 1993, the animals grazed a lodgepole pine forest site during early summer. The density of Columbia milkvetch and its basal area were similar at both locations. The Columbia milkvetch was not a preferred species on the grassland site as indicated by the bite count technique that determined its percentage in the diet. Consumption of Columbia milkvetch increased gradually as other forage species were preferentially selected and depleted. On the grasslands, consumption of Columbia milkvetch by individual animals did not show an addictive pattern. At the forest site, utilization of Columbia milkvetch was determined on a weekly basis during 1992 and on a biweekly basis during 1993 by paired plots. In contrast to the grassland site, Columbia milkvetch was a preferred species at the forest site where it was utilized to a greater extent than grasses or other forbs. Approximately $80 \%$ of the Columbia milkvetch was utilized during 1992 and $60 \%$ during 1993, which was significantly greater than the utilization of grasses or other forbs. Forage nutrient analysis at the forest site indicated Columbia milkvetch had higher crude protein and lower ADF content than other forages but it caused livestock poisoning in 1993.
\end{abstract}

Key Words: poisonous plants, timber milkvetch, Astragalus miser var. serotinus, diet selection

The Interior Douglas-fir (Pseudotsuga menziesii (Mirb.) Franco) zone is the most important grazing range in British

The authors would like to thank Cindy Hunter, Wendy Pepper and Monica Durigon for assistance in collection of field data: Greg Syme for care of livestock: Chuck Kalnin for forage nutrient analysis; and the B.C. Ministry of Forests, 100 Mile District for their commitment to the project.

The study was partially funded by the Agri-Food Regional Development Subsidiary Agreement (project \#11010) and by the B.C. Ministry of Agriculture, Fisheries and Food Demonstration of Agricultural Technology and Economics Program (D.A.T.E. project \#337). We would like to thank Uniblok Canada, Rockyford, Alberta for supplying the molasses blocks.

Manuscript accepted 24 Aug. 1995.
Columbia (Wikeem et al. 1993) and it accommodates approximately 0.3 million beef cows and calves (Agriculture Canada 1989). Forest fires and recent logging have replaced Douglas-fir, the climax dominant, with lodgepole pine (Pinus contorta (Moench) Voss) over extensive areas (Tisdale and McLean 1957) and this trend continues. Columbia milkvetch (Astragalus miser Dougl. ex Hook. var. serotinus), also known as timber milkvetch, is found mainly in this zone and in the associated rough fescue (Festuca scabrella Torr.) grassland communities of southern British Columbia (Taylor 1974). Columbia milkvetch and other species of Astragalus synthesize large quantities of miserotoxin (Williams 1982; Quinton et al. 1989) and other glycosides of 3nitropropanol (Long et al. 1992) that cause acute and chronic poisoning in ruminants (Majak and Pass 1989).

There is a dearth of knowledge on the selection and utilization of Columbia milkvetch by cattle.Some observers suggest that cattle are addicted to the forb. However, preliminary field observations indicated that the plant was avoided on grasslands (Quinton et al. 1989). This study examines the utilization of Columbia milkvetch by cattle grazing 2 different range types, an upper grassland community in late spring and a lodgepole pine forest in early summer.

\section{Materials and Methods}

The study was located at Long Lake, a grassland site $11 \mathrm{~km}$ north of Kamloops, B.C., and at Sixtyone Creek, a forested site $18 \mathrm{~km}$ north of Clinton, B.C. The soils and the latitude-longitude notation of these sites were similar to those described previously (Majak and Wikeem 1986). At the time of grazing, the Columbia milkvetch was in the bud to bloom stage of growth at both sites. The cattle used in the study were 2 to 11 year-old Hereford cows with calves. Water was available at all times and, except for one trial on the forested site in 1993, all cattle were supplemented with molasses blocks containing $25 \%$ crude protein. At both sites, pastures were grazed to approximately $50 \%$ of available forage.

\section{Grasslands}

The Long Lake grassland site (elevation $900 \mathrm{~m}$ ) consisted of 2 adjacent 10 ha pastures (north and south).The major grasses were rough fescue, Kentucky bluegrass (Poa pratensis L.) and Richardson's needlegrass (Stipa richardsonii Link) and the major 
forbs were strawberry (Fragaria virginiana Duch.) and yarrow (Achillea millefolium L.). Each pasture was grazed by ten Hereford cows and their calves from 3 May to 19 June 1990 and from 6 May to 19 June 1991.

Columbia milkvetch density and basal area, the area of the crown, were determined by counting the number of plants in 400 , $50 \times 20 \mathrm{~cm}$ plots along 4 lines (100 plots per line) and measuring them with a basal area ruler.The plots were 5 to $7 \mathrm{~m}$ apart, depending on the length of the transect line.

Diet selection during the trial was estimated with direct observation between 0700 and 2000 hours on 16 days in 1991 and on 12 days in 1990 using the bite count technique (Reppert 1960). Each cow was followed by 1 of 3 observers who recorded a minimum of 250 bites per grazing time to establish the percentage of Columbia milkvetch in the diet. Ten to 20 individual diets were recorded on each sampling day. Diets were recorded on 464 occasions during 1990 to 1991 .

At the conclusion of the grazing trial, 10 composite samples of Columbia milkvetch, grasses, and forbs were oven-dried to a constant weight at $60^{\circ} \mathrm{C}$ for nutrient analyses.

\section{Forest}

The lodgepole pine forest site at Sixtyone Creek (elevation $1,100 \mathrm{~m}$ ) consisted of two, 40 ha pastures (A and B) $0.6 \mathrm{~km}$ apart. The trees were 121 to 140 years old, 10.5 to $19.4 \mathrm{~m}$ in height, and with a density of approximately 300 trees per ha. The principal grass was pinegrass (Calamagrostis rubescens Buckl.) and the major forbs were dandelion (Taraxacum officinale Weber) and oyster plant (Tragopogon dubius Scop.). Columbia milkvetch density and basal area were determined by the same method used on the grassland site but with 8 lines and 800 plots. Direct observations on diet selection on a daily basis were not feasible on the forested site due to constraints of limited manpower and the remoteness of the site. Therefore, selection of Columbia milkvetch, grasses, and forbs during the trial period was determined as the difference in their biomass estimates on grazed and caged plots. A limited number of direct observations on diet selection were also made.

In 1992, each pasture was divided, with electric fence, into quarters of 10 ha each and grazed with 10 cow-calf pairs in succession for 1-week periods from 26 May to 26 June. In 1993, each 40-ha pasture was divided in half and groups of 10 cow-calf pairs grazed each half in succession for 2 weeks from 16 June to 19 July. Five paired, $1-\mathrm{m}^{2}$ plots were randomly established in each quarter-pasture in 1992 and 10 in each half-pasture in 1993 but their distribution was constrained by the need to include Columbia milkvetch. The selection of plots containing Columbia milkvetch overestimated its biomass in the pasture. However, the objective of the study was not to determine Columbia milkvetch biomass in the pastures but rather to determine the degree to which Columbia milkvetch was utilized. The plots were clipped after each successive grazing period to determine forage production and utilization. Indices of relative preference were calculated by Krueger's second equation (Krueger 1972). The clipped material was oven-dried and analysed for crude protein and ADF content by conventional procedures (AOAC 1990; Waldern 1971).

\section{Statistical Analysis}

For Columbia milkvetch density and basal area, the design was fully nested with sites, pastures within sites, and transects within pastures. Differences between sites and pastures within sites were compared by analysis of variance (ANOVA) using pastures within sites and transects within pastures as the respective error terms. The percentage of Columbia milkvetch in the diet derived from the bite counts on the grassland site was examined with the following sources of variation: year, pasture, date within year, cows within pasture by year, the pasture $X$ year interaction and the date $X$ pasture interaction within each year. The error term for testing years and pastures was the year $X$ pasture interaction; for date within year it was date $X$ pasture interaction within each year; for cows within pasture by year and the date $X$ pasture interaction within each year it was the residual error; and for pasture $X$ year it was a composite of cows within pasture by year and pasture $X$ date interaction within each year. ANOVA was constructed using the procedures of the SAS Institute Inc. (1985). The utilization percentages of Columbia milkvetch, grasses and forbs, derived from clipping plot pairs were correlated repeated measures of forage utilization. Using repeated measures ANOVA, differences between pastures at each site and in each year were tested against the variability among plot pairs within pastures. Differences among the 3 plant types were tested against the plant type $\times$ plot interaction within each pasture. At the grassland site, the 2 years were also compared and the pasture $X$ year interaction tested by treating years as a split plot factor and testing them against the residual variance. A correlation coefficient was calculated to compare the consumption of Columbia milkvetch by individual animals between years.

\section{Results and Discussion}

Columbia milkvetch density or basal area were similar $(\mathrm{P}>0.1)$ between grassland and forest sites (Table 1). There was no detectable difference in Columbia milkvetch density between

Table 1. Columbia milkvetch density and average basal area at 2 rangeland sites in British Columbia.

\begin{tabular}{lccc}
\hline \hline Site & Pasture & Density & Basal area \\
\hline \multirow{2}{*}{ Long Lake (grassland) } & north & (plants $\mathrm{m}^{-2}$ ) & (cm $^{2}$ plant ${ }^{-1}$ ) \\
& south & 27.2 & 2.5 \\
SE & & 15.4 & 2.1 \\
Sixtyone Creek (forest) & A & 4.2 & 0.3 \\
& B & 11.0 & 3.0 \\
SE & & 12.6 & 2.5 \\
\hline
\end{tabular}

pastures at the forest site but at the grassland site, the north pasture had almost twice as many Columbia milkvetch plants as the south pasture $(\mathrm{P}<0.01)$. The average basal area of Columbia milkvetch plants did not differ between sites or between pastures $(\mathrm{P}>0.1)$. Previously, we reported that the biomass of Columbia milkvetch plants growing on grassland and forest range was also similar (Majak et al. 1988). The similarity in Columbia milkvetch density and basal area between the grassland and forest sites permits comparisons of grazing behaviour with respect to Columbia milkvetch. 


\section{Grasslands}

When the percentage of Columbia milkvetch in the diet was examined as a function of time, a significant pasture $X$ date interaction ( $\mathrm{P}<0.01$ ) was detected in 1990 (Fig. 1). During May, the selection of Columbia milkvetch by cattle was similar in both pastures but in June, their feeding behaviour changed. As the consumption of Columbia milkvetch increased in the one pasture, it decreased in the other and vice versa (Fig. 1). The sudden decrease in the south pasture, which also contained 50\% less Columbia milkvetch (Table 1), might be attributed to a depletion of Columbia milkvetch biomass. There was above average rainfall in the spring of 1990 (Atmospheric Environment Service $1990 ; 1991$ ) and it is possible that the moisture rendered the Columbia milkvetch more succulent and palatable. We have shown previously that the toxicity and moisture content of Columbia milkvetch can be influenced by rainfall events (Majak et al. 1976). There were no pasture $X$ date interactions in 1991 (Fig. 1). The average percentage of Columbia milkvetch in the diet was 8.4 in the north pasture and 6.4 in the south pasture. In general, there was a gradual, linear $(P<0.01)$ increase in the consumption of Columbia milkvetch during 1990 and 1991 (Fig. 1). The results indicated that on upper grasslands, Columbia milkvetch is not a preferred species if there is an abundance of other grasses and forbs, which are selected first.

Direct observation on forage selection showed that cattle in the north pasture selected a higher proportion of Columbia milkvetch than in the south pasture in 1990 but not in 1991. In 1990, the

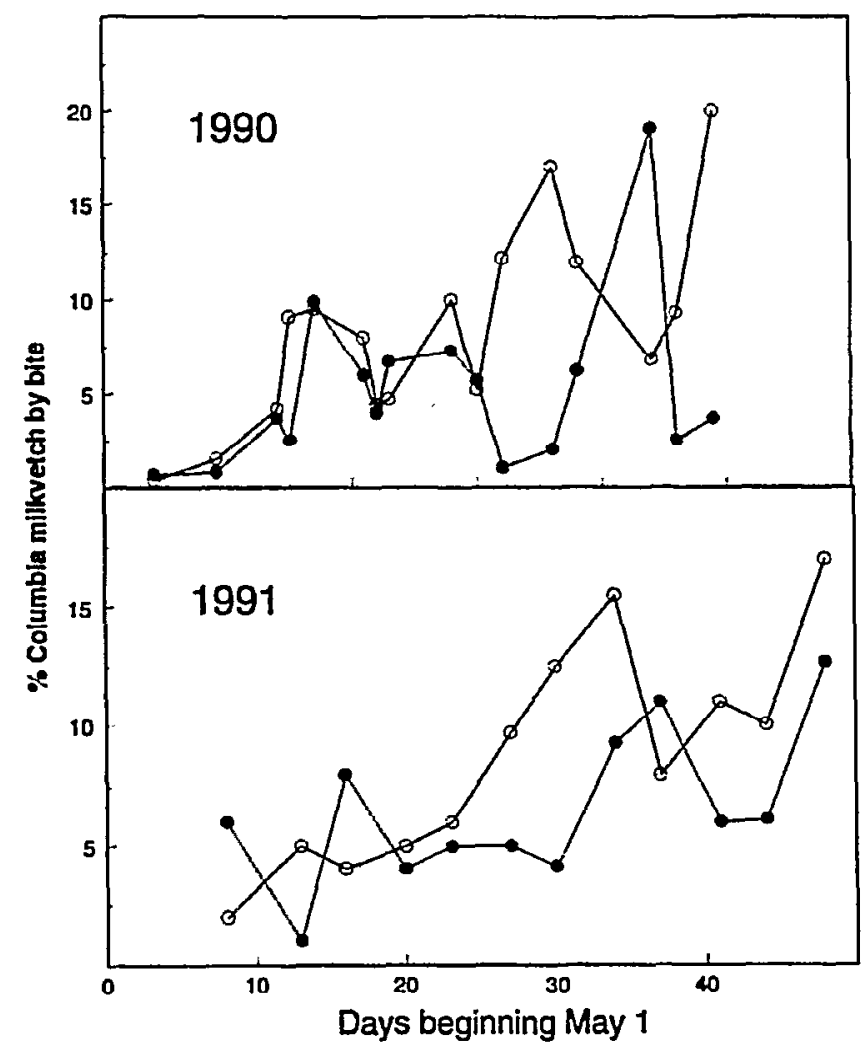

Fig. 1. Average daily percentage of Columbia milkvetch in the diet of cattle on the grassland site during 1990 and 1991 in the south (solid circles) and north (open circles) pastures as estimated by the bite count technique. SE $(1990)=1.61$; SE $(1991)=1.78$.
Table 2. Crude protein and ADF content of 3 types of forages at the grassland and forest sites in interior British Columbia.

\begin{tabular}{|c|c|c|c|c|}
\hline Site & Date & Forbs & Grasses & $\begin{array}{l}\text { Columbia } \\
\text { milkvetch }\end{array}$ \\
\hline \multirow[t]{8}{*}{ Long Lake- } & \multicolumn{4}{|c|}{$\ldots \ldots \ldots$ Crude protein $(\%)-\ldots \ldots$} \\
\hline & June 26, 1990 & 9.9 & 6.8 & 15.9 \\
\hline & June 20, 1991 & 9.0 & 6.2 & 15.0 \\
\hline & SE & 0.4 & 0.3 & 0.7 \\
\hline & \multicolumn{4}{|c|}{ - } \\
\hline & June 26, 1990 & 36.8 & 45.8 & 33.3 \\
\hline & June 20,1991 & 34.0 & 44.3 & 29.6 \\
\hline & $\mathrm{SE}$ & 1.2 & 1.0 & 0.9 \\
\hline \multirow[t]{8}{*}{ Sixtyone Creek } & \multicolumn{4}{|c|}{$\ldots$} \\
\hline & June 30, 1993 & 10.5 & 8.7 & 19.4 \\
\hline & July 14,1993 & 10.1 & 8.0 & 17.7 \\
\hline & SE & 0.5 & 0.3 & 0.7 \\
\hline & \multicolumn{4}{|c|}{$\ldots$ ADF $(\%)$} \\
\hline & June 30,1993 & 25.8 & 41.8 & 27.2 \\
\hline & July 14,1993 & 29.3 & 41.2 & 30.9 \\
\hline & SE & 2.0 & 0.5 & 0.9 \\
\hline
\end{tabular}

average Columbia milkvetch consumption was $11.2 \%$ in the north pasture and $5.4 \%$ in the south pasture (SE $=2.25$ ). The average Columbia milkvetch consumption was $7.2 \%(\mathrm{SE}=2.22)$ at the grassland site in 1991. The higher density of Columbia milkvetch in the north pasture may have influenced the higher percentage of Columbia milkvetch in the diet. There were no clinical signs of Columbia milkvetch poisoning among cattle at the grassland site in either year. Of the 20 cows used in 1990, 17 were again used in 1991 without showing any ill effects. Columbia milkvetch consumption by individual animals was not significantly correlated between years $(r=0.18)$.

Plant nutrient data from the clipped plants showed that Columbia milkvetch had a greater crude protein content than grasses or forbs (Table 2). The grasses were mature at the time it was sampled and showed a lower protein content and higher $\mathrm{ADF}$, while forbs were intermediate in protein content (Table 2).

\section{Forest Range}

Data from the grazed and caged paired plots at the forest site indicated cattle consumed forage consisting of approximately $52 \%$ grasses, $13 \%$ forbs and $35 \%$ Columbia milkvetch. No differences were detected in the percent utilization of grasses and forbs at the forest site (Fig. 2), nor were there differences between pastures $(P>0.5)$. The utilization of Columbia milkvetch was higher $(\mathrm{P}<0.01)$ than the utilization of grasses and forbs in both years (Fig. 2). In 1993, there appeared to be a lower utilization of vetch than in 1992. The grazing trial started 3 weeks later in 1993 than in 1992 and more Columbia milkvetch biomass was probably available in 1993. Utilization data for the forest site, obtained on a weekly basis during 1992 and biweekly during 1993, showed that vetch was a highly preferred species being continually utilized throughout the entire grazing period (Fig. 3). The results for 1993 were confirmatory: on 30 June 1993 after 2 weeks of grazing, $69 \%$ of the Columbia milkvetch had been utilized but only $55 \%$ of the forbs and grasses. Two weeks later, on 14 July 1993, Columbia milkvetch utilization declined to $52 \%$, grass utilization had not changed, and forb utilization declined to $40 \%$. When relative preferences were calculated (Krueger 1972) the indices 


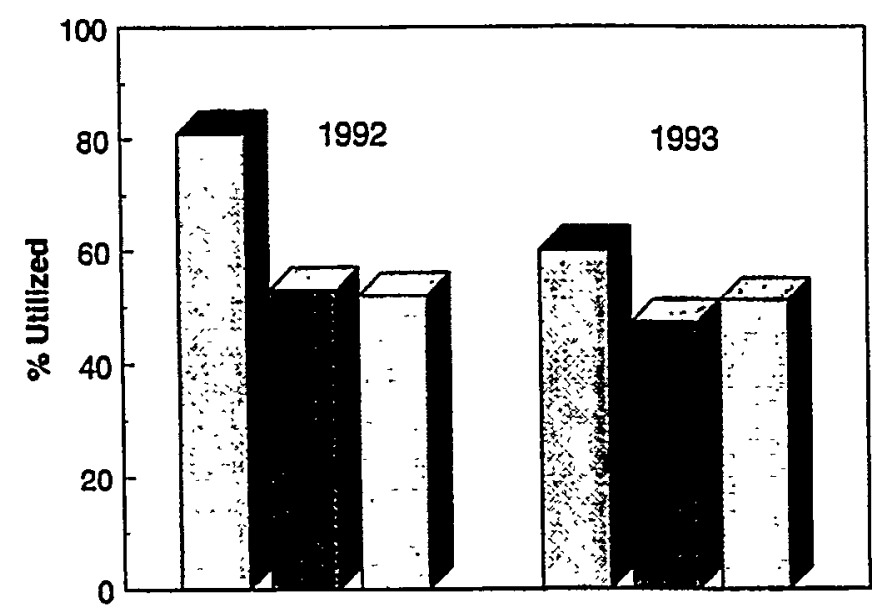

Fig. 2. Average percentage utilization of forage by cattle at the forest site during 1992 and 1993 as estimated by harvesting paired plots. $\mathrm{SE}($ vetch) $=5.0, \mathrm{SE}$ (forbs) $=8.4$, and $\mathrm{SE}$ (grasses) $=6.1$.

ranged from 1.12 to 1.33 (mean 1.23 ) for Columbia milkvetch, 0.85 to 0.94 (mean 0.89 ) for grasses, and 0.59 to 1.00 (mean 0.83 ) for forbs. In short, our results demonstrate that Columbia milkvetch can be a preferred species when it is growing in a stand of less palatable forage such as pinegrass, which accumulates high levels of silica (McLean et al. 1969). Periodic direct observations on forage selection confirmed the early and continual consumption of Columbia milkvetch at the forest site. There was no field evidence of Columbia milkvetch avoidance by cattle.

\section{Management Implications}

Over most of the grazing period, Columbia milkvetch did not appear to be a preferred forage at the grassland site (Fig. 1). Our policy of grazing pastures to within approximately $50 \%$ of avail-

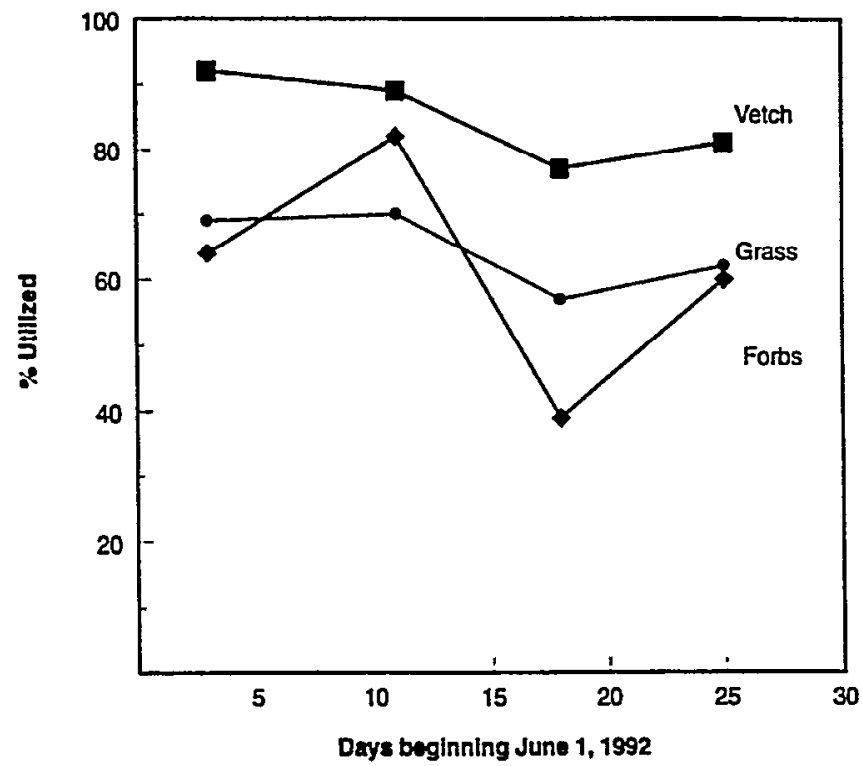

Fig. 3. Percentage utilization of Columbia milkvetch, forbs, and grass on a weekly basis at the forest site in interior British Columbia in June 1992 as estimated by harvesting paired plots. able forage clearly showed avoidance of Columbia milkvetch by cattle at the grassland site but not at the forest site.

At the forest site, consumption of Columbia milkvetch by cattle could be conducive to poisoning. Although none of the cattle were poisoned in 1992, three animals showed mild to acute symptoms of poisoning 3 weeks after commencement of grazing in 1993 on pasture A (Table 1). These animals were all 2-yearold first-calf heifers used for the first time in Columbia milkvetch studies. They were also part of a group of cattle not receiving protein supplements for the first time. There is a growing body of evidence that indicates ruminal detoxification of Columbia milkvetch can be enhanced with protein supplements (Majak 1992; Anderson 1995). The absence of these supplements may have increased the susceptibility of these animals to Columbia milkvetch poisoning. There was no evidence to indicate that the protein supplement reduced the intake of vetch on pasture $B$.

During the entire study for 1992, the protein level in Columbia milkvetch was approximately twice as great as the level in the grass (Fig. 4). The Columbia milkvetch was probably a major source of protein at the forest site and its digestibility was superior to the grasses, mainly pinegrass, as indicated by the ADF content in 1992 (Fig. 4) and in 1993 (Table 2). However, Columbia milkvetch was probably less than $30 \%$ of the diet and other forage components at the forest site were low in protein (Table 2, Fig. 4). When cattle were poisoned in 1993, the miserotoxin content of the Columbia milkvetch on a dry matter basis was $2.51 \% \pm 0.25$ (SD) as determined by HPLC (Majak et al. 1988; Quinton et al. 1989). Although these are relatively low concentrations, it should be reiterated that more toxin per plant becomes available as the biomass of the plant increases (Majak et al. 1988).

In summary, Columbia milkvetch is a digestible and nutritious forage but it can be toxic. Cattle avoided Columbia milkvetch on the grassland site, selecting more palatable forages first and consuming increasing amounts of Columbia milkvetch as other species became depleted. There was no evidence of addiction to

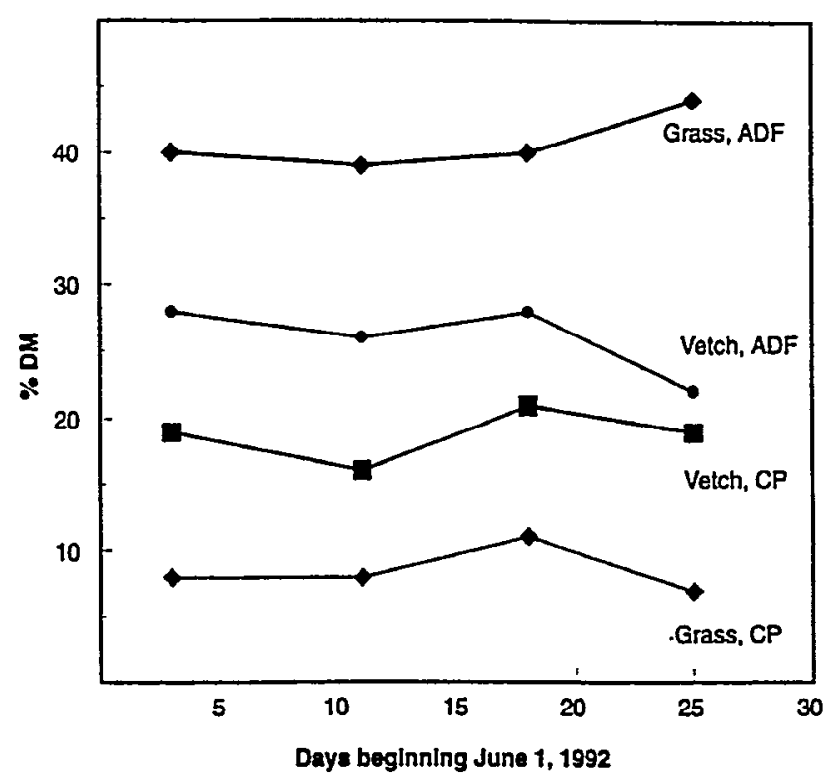

Fig. 4. Crude protein (CP) and ADF content in Columbia milkvetch and grass at the forest site during June 1992. $\mathrm{SE}(\mathrm{CP})=0.55$, $\operatorname{SE}(\mathrm{ADF})=0.71$. 
Columbia milkvetch on the grassland site. In contrast, Columbia milkvetch was a preferred forage at the forest site, probably because it was associated with pinegrass which is less palatable.

\section{Literature Cited}

Agriculture Canada. 1989. Development of the agri-food sector in British Columbia. Appendix commodity profile. Forages. Agriculture Canada, New Westminster, B.C.36 pp.

Anderson, R.C. 1995. Enrichment, isolation and characterization of a nitropropanol metabolizing bacterium from the rumen. Ph.D. Thesis, Iowa State University, Ames, Iowa.

Association of Official Analytical Chemists International. 1990. Official methods of analysis. Vol. I, 15th ed., AOAC, Arlington, VA.

Atmospheric Environment Service. 1990, 1991. Monthly record. Meteorological observations in Western Canada. April, May, June. Environment Canada, Atmos. Environ. Serv., Downsview, Ontario.

Krueger, W.C. 1972. Evaluating animal forage preference. J. Range Manage. 25:471-475

Long, M., M. Benn, W. Majak, and R. McDiarmid. 1992. 3Nitropropyl glycosides of Astragalus miser var. serotinus. Phytochemistry 31:321-323.

Majak, W. 1992. Further enhancement of 3-nitropropanol detoxification by ruminal bacteria in cattle. Can. J. Anim. Sci. 72:863-870.

Majak, W. and M.A. Pass. 1989. Aliphatic nitrocompounds, p. 143159.In: P.R. Cheeke (ed.), Toxicants of Plant Origin, Vol. II Glycosides. CRC Press Inc., Boca Raton, Fla.
Majak, W. and B.M. Wikeem. 1986. Miserotoxin levels in fertilized Astragalus miser var. serotinus. J. Range Manage. 39:130-131.

Majak, W., D.A. Quinton, H.E. Douwes, J.W. Hall, and A.D. Muir. 1988. The effect of clipping on the growth and miserotoxin content of Columbia milkvetch. J. Range Manage. 41:26-29.

Majak, W., R.J. Williams, A.L. van Ryswyk, and B.M. Brooke. 1976. The effect of rainfall on Columbia milkvetch toxicity. J. Range Manage. 29:281-283.

McLean, A., S. Freyman, J.E. Miltimore, and D.M. Bowden. 1969. Evaluation of pinegrass as range forage. Can. J. Plant Sci. 49:351-359.

Quinton, D.A., W. Majak, and J.W. Hall. 1989. The effect of cattle grazing on the growth and miserotoxin content of Columbia milkvetch. J. Range Manage. 42:368-371.

Reppert, J.N. 1960. Forage preference and grazing habits of cattle at the Eastern Colorado Range Station. J. Range Manage. 13:58-62.

SAS Instifute Inc. 1985. SAS user's guide: Statistics. Version 5 ed. SAS Institute Inc., Cary, N.C.

Taylor, T.M.C. 1974. The Pea Family (Leguminosae) of British Columbia. Royal B.C. Provincial Museum, Victoria, B.C.

Tisdale, E.W. and A. McLean. 1957. The Douglas fir zone of Southern British Columbia. Ecol. Monogr. 27:247-266.

Waldern, D.E. 1971. A rapid micro-digestion procedure for neutral and acid detergent fiber. Can. J. Anim. Sci. 51:67-69.

Wikeem, B.M., A. McLean, A. Bawtree, and D. Quinton. 1993. An overview of the forage resource and beef production on Crown land in British Columbia. Can. J. Anim. Sci. 73:779-794.

Williams, M.C. 1982. 3-Nitropropionic acid and 3-nitro-1-propanol in species of Astragalus. Can. J. Bot. 60:1956-1963. 